\title{
Mapping savanna ecosystems of the Llanos del Orinoco using multitemporal NOAA satellite imagery
}

\author{
Eulogio J. Chacón-Moreno* \\ Fac: de Ciencias. Instituto de Ciencias Ambientales y Ecológicas (ICAE), Universidad de Los Andes. Mérida SIOI. Venezuela
}

Received 14 February 2003; accepted 2I August 2003

\begin{abstract}
Monthly composites NOAA-advanced very high resolution radiometer (AVHRR) normalized difference vegetation index (NDVI) images (June 1992-October 1993) were used to analyze the phenology of savanna ecosystems in the Llanos del Orinoco region. The objective was to elaborate an ecosystems map of the area based on the temporal pattern analysis. Expert knowledge of savannas allowed the selection of representative ecosystems to monitor changes in NDVI. From 54 satellite images, model curves were created for each selected ecosystem. They were analyzed with the objective to characterize and identify each ecosystem. From these temporal patterns and statistical analyses, six satellite images were chosen to carry out a supervised classification using Mahalanobis distance methodological approach. Validation of the map was implemented using ground control points. Differences in phenology between ecosystems are strongly related to the environmental climatic conditions, especially to seasonal rainfall. Therefore, the phenology for each ecosystem can be explained based on water availability. A methodological approach, which reveals the phenology of the most important savanna ecosystems in Venezuela. was applied in this work. This study represents an improvement in mapping of ecological processes.
\end{abstract}

(C) 2003 Elsevier B.V. All rights reserved.

Keywords: Vegetation phenology; NDVI; Ecological map; Supervised classification; Venezuela

\section{Introduction}

The tropical savanna ecosystem, Llanos del Orinoco, constitutes the major region of northern South America (Sarmiento, 1983, 1990). The phenological variation of the vegetation is related to environmental conditions. These vegetation-environment relationships have been used to classify the savanna ecosystem in the Llanos, which mainly reflects climatic seasonality and geomorphological features (Sarmiento, 1990).

The Llanos del Orinoco area is not a large homogeneous savanna area as suggested by continental veg-

\footnotetext{
- Tel.: +58-274-2401286

E-mail address: eulogio@ula.ve (E.J. Chacón-Moreno).
}

etation maps (Hueck and Seibert, 1988; Stone et al., 1994; Batista et al., 1997; Loveland and Belward, 1997; Loveland et al., 1999); it represents a variety of savanna ecosystems. Vegetation maps of Venezuela show a variety of taxonomic plant communities, which are related to environmental features like climate, geomorphology and soil (MARNR, 1983; Huber and Alarcón, 1988). However, some of these maps reflect the spatial features of the vegetation, but do not include the ecological processes associated with ecosystem functioning. We will explore the ecological potential of including phenological information to map the ecosystems of the Llanos of northern South America.

NOAA-advanced very high resolution radiometer (AVHRR) images and the normalized difference vegetation index (NDVI) have been used in many studies to 
understand the relation between the spectral variability and the vegetation vigour or growth rate, and it is useful to determine the production of green vegetation and detect vegetation changes (Hobbs, 1989; Groten, 1993a,b; Stone et al., 1994; Batista et al., 1997; Duchemin et al., 1999; Kressler and Steinnocher, 1999). Multitemporal low resolution NOAA-AVHRR NDVI imagery has been used to reveal variations in vegetation phenology of temperate deciduous forest ecosystems (Duchemin et al., 1999), different vegetation types in the USA (Reed et al., 1994), Amazonian forests (Batista et al., 1997), pasture and grass ecosystems (Hill et al., 1999) and continental isogrowth zones (Menenti et al., 1991; Azzali and Menenti, 1999).

Vegetation phenology has been associated with seasonal climatic patterns in temperate vegetation and agriculture areas (Reed et al., 1994). So far no attempt has been made to relate the phenological patterns of the Llanos del Orinoco vegetation to remotely sensed NDVI time series. The variety of savanna ecosystems in the Llanos del Orinoco is mainly due to the phenological responses of vegetation to environmental conditions (climate, soil nutrients, topography, etc.). Its phenological responses have been used to classify the savanna ecosystems (Chacón-Moreno, 1991). One of the classifications of savanna ecosystems is based on hydrological dynamics (Sarmiento, 1984, 1990), in which soil water availability during the year determines ecological characteristics associated with deficit or excess of water in the soil. From the hydrological point of view, a direct association between savanna ecosystems and phenological patterns can be determined (Monasterio and Sarmiento, 1976; Sarmiento, 1984).

Knowledge of functioning, ecological processes and the phenology relationship of the main savanna ecosystems will be used to link the multitemporal NOAA-AVHRR NDVI imagery in order to identify phenological patterns of the savanna ecosystems, and to develop a map of the different ecosystems of the Llanos del Orinoco. The main tasks considered in this work are the analysis of multitemporal images to determine seasonal curves of NDVI; a selection, based on statistical considerations, of the images to use in the classification process; a supervised classification to obtain a map displaying a number of ecosystem classes that differ in phenological feature, and an assessment of map accuracy with ground data.

\section{Methods}

\subsection{Study area}

The Llanos del Orinoco is a quaternary basin with an area of about $240,000 \mathrm{~km}^{2}$. At the regional scale, the Llanos del Orinoco is classified in four main units based on geology, soil, geomorphology and climate (Sarmiento, 1983): the piedmont or footslope savanna; the high plain or tertiary plateau; the alluvial plain or flooding savanna, and the aeolian plains or aeolian savanna. Further descriptions and maps of the main units is given in Sarmiento (1983) and Acevedo and Silva (1985).

Ecosystem typology for tropical savannas is derived from Sarmiento (1984), where the soil for each ecosystem has different periods of water availability, deficit or excess, and the period of green vegetation may be differentiated in time. Seasonal savannas are the areas with herb cover, mainly grasses, with two hydrological seasons: a dry season with duration between 4 and 6 months, and another ecologically favorable season with availability of water in the soil. The vegetation responds to one long period of stress. Hyperseasonal savannas are ecosystems with four different hydrological conditions during the year, a first dry period of approximately 2 or 3 months; a second period with availability of water in the soil which lasts 1 or 2 months; a third period with excess water in the soil, with a duration of approximately 6-7 months, and a fourth ecologically favorable period with a duration of I month. Plants suffer from two different stress conditions; caused by dry soil and by excess of water. Semiseasonal savannas are ecosystems with two periods: a favorable one with a duration of 2-3 months, and a long period of approximately 9 months with excess water in the soil. Species distribution and response are driven by excess water during a long period. Fig. 1 presents the main field observations on the relation between seasonality and savanna ecosystems.

Supplementary information on the study area and environmental features were derived from vegetation, geological, topographical, and climatic maps of Venezuela (MARNR, 1983; Huber and Alarcón, 1988), a vegetation map of South America (Hueck and Seibert, 1988), and climate data. Further non-spatial descriptions of the Llanos del Orinoco are presented in Chacón-Moreno (1991). 


\begin{tabular}{|c|c|c|c|c|c|c|c|c|c|c|c|c|c|}
\hline & Month & $\mathrm{J}$ & $F$ & $M$ & A & $M$ & $\mathrm{~J}$ & $\mathrm{~J}$ & $\bar{A}$ & $S$ & 0 & $\mathrm{~N}$ & $D$ \\
\hline & Seasonal condition & $\cdot$ & - & - & $+\cdot$ & + & + & + & + & + & + & +- & $=$ \\
\hline \multirow{3}{*}{ 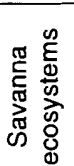 } & Seasonal & & & & & & & & & & & & \\
\hline & Hyperseasonal & & & & & & & & & & & & \\
\hline & Semiseasonal & & & & & & & & & & & & \\
\hline
\end{tabular}

Fig. 1. Scheme displaying period of rainfall and phenological condition for three savanna ecosystems in the Llanos del Orinoco, Venezuela. Minus ( - ) and plus (+) signs denote quantity on rainfall. Black: flooded and submergence of vegetation; gray: green vegetation; white: dead/dry vegetation.

\subsection{Sources of data}

The primary data sources for this work were $1 \mathrm{~km}$ images of NOAA advanced very high resolution radiometer. The images were obtained from the global land $1 \mathrm{~km}$ data set project, under the guidance of the International Geosphere Biosphere Program (Loveland and Belward, 1997; Loveland et al., 1999). The data was collected continuously for 18 consecutive months beginning 1 April 1992, and continuing through 30 September 1993 (54, 10 days image composition). Processing standards for the AVHRR data have been developed for calibration, atmospheric correction, geometric registration, and the production of global 10-day maximum normalized difference vegetation index composites. Further descriptions of image processing for NOAA-AVHRR are detailed in Eidenshink and Faundeen (1998).

\subsection{Processing of multitemporal NOAA satellite imagery and sampling areas}

The selection of the areas is based on information from previous maps (MARNR, 1983; Huber and Alarcón, 1988) and personal knowledge of the study area. Analysis of multitemporal NDVI-NOAA imagery was carried out to determine phenological patterns of ecosystems into the Llanos del Orinoco region. The sampling was made considering the major savanna ecosystem types of the Llanos del Orinoco (Table 1).

The 10 selected areas are described in Table 2. The features of ecosystem, vegetation, climate and soil are derived from Ramia (1959), Sarmiento and Monasterio (1971, 1975), Monasterio et al. (1971), Sarmiento et al. (1971a,b), Silva et al. (1971), Monasterio and Sarmiento (1976), Sarmiento (1983, 1984), and Chacón-Moreno (1991). Using the information derived from S10 (control area), 8 of 54 images were excluded because the cloud cover was too extensive. From the sampled areas, the S3, S4, S5, S6 and S7 were used for the analysis. The other sampled areas, containing information about agriculture use, forest vegetation, and savanna ecosystems outside of Venezuela, were used to compare and complement the information. Each selected area has more than 30 pixels per ecosystem for the 54 NDVI-NOAA images.

Table I

Distribution of phenological ecosystem types over the three different main geomorphological regional systems

\begin{tabular}{|c|c|c|c|c|c|c|c|}
\hline \multirow{2}{*}{$\begin{array}{l}\text { Llanos del } \\
\text { Orinoco regions }\end{array}$} & \multicolumn{7}{|c|}{ Savanna ecosystems } \\
\hline & $\begin{array}{l}\text { Gallery } \\
\text { forest }\end{array}$ & $\begin{array}{l}\text { Seasonal } \\
\text { forest }\end{array}$ & $\begin{array}{l}\text { Seasonal } \\
\text { savanna }\end{array}$ & $\begin{array}{l}\text { Hyperseasonal } \\
\text { savanna }\end{array}$ & $\begin{array}{l}\text { Semiseasonal } \\
\text { savanna }\end{array}$ & $\begin{array}{l}\text { Irrigated } \\
\text { agriculture }\end{array}$ & $\begin{array}{l}\text { Rainfed } \\
\text { agriculture }\end{array}$ \\
\hline Piedmont & + & + & ++ & & & + & ++ \\
\hline Tertiary plateau & + & & ++ & + & & + & + \\
\hline Alluvial plains & + & + & + & ++ & ++ & ++ & + \\
\hline Aeolian plains & + & & + & ++ & + & & \\
\hline
\end{tabular}


Table 2

Sampling areas selected for the analysis of phenological patterns of savanna ecosystems

\begin{tabular}{|c|c|c|c|c|}
\hline Code & Location name & Ecosystem & Features & Coordinates \\
\hline SI & $\begin{array}{l}\text { Calabozo irrigated } \\
\text { rice crop area }\end{array}$ & lrrigated agriculture & $\begin{array}{l}\text { Irrigated crops on extensive area. using } \\
\text { irrigation from water reserve. Intensive } \\
\text { agriculture. Rice crops. Alluvial overflow } \\
\text { subregion, close to high plains subregion. }\end{array}$ & $\begin{array}{l}\text { Latitude: } 8.45 \text {, } \\
\text { longitude: }-67.50\end{array}$ \\
\hline S2 & $\begin{array}{l}\text { Orinoco river and } \\
\text { Meta river borders }\end{array}$ & Gallery forest & $\begin{array}{l}\text { Rivered and gallery forest occurring } \\
\text { along of permanent watercourse (rivers). }\end{array}$ & $\begin{array}{l}\text { Latitude: } 7.00 \text {, } \\
\text { longitude: }-67.2\end{array}$ \\
\hline S3 & Tertiary plateau area $\mathbf{I}$ & Seasonal savanna & Savanna parkland on the high plains. & $\begin{array}{l}\text { Latitude: } 8.6 \text {, } \\
\text { longitude: }-67.2\end{array}$ \\
\hline S4 & Tertiary plateau area II & $\begin{array}{l}\text { Seasonal-hyper- } \\
\text { seasonal savanna }\end{array}$ & $\begin{array}{l}\text { Savanna areas with palm and frequently } \\
\text { flooded. Located on high plains. }\end{array}$ & $\begin{array}{l}\text { Latitude: } 8.6 \\
\text { longitude: }-67.2\end{array}$ \\
\hline S5 & Camaguan Esteros & $\begin{array}{l}\text { Semiseasonal } \\
\text { savanna }\end{array}$ & $\begin{array}{l}\text { Esteros (semiseasonal savanna) mixed } \\
\text { with palm and semiseasonal forest. } \\
\text { Located on Alluvial overflow plains. }\end{array}$ & $\begin{array}{l}\text { Latitude: } 8 \text {, } \\
\text { longitude: }-67\end{array}$ \\
\hline S6 & $\begin{array}{l}\text { Apure flooding } \\
\text { areas between large } \\
\text { rivers (Apure and } \\
\text { Arauca rivers) }\end{array}$ & $\begin{array}{l}\text { Hyperseasonal and } \\
\text { semiseasonal savanna }\end{array}$ & $\begin{array}{l}\text { Savanna areas, which are flooded } \\
\text { during } 3-4 \text { months per year. } \\
\text { Herbaceous vegetation. Located on } \\
\text { alluvial overflow plains. }\end{array}$ & $\begin{array}{l}\text { Latitude: } 7.50 \text {, } \\
\text { longitude: }-69\end{array}$ \\
\hline S7 & $\begin{array}{l}\text { Piedmont areas } \\
\text { (Footslope plains) }\end{array}$ & $\begin{array}{l}\text { Seasonal savanna and } \\
\text { disturbed areas }\end{array}$ & $\begin{array}{l}\text { Savanna parkland on low terraces. } \\
\text { Disturbed by annual crops and extensive } \\
\text { grazing. Located on Andean footslope. }\end{array}$ & $\begin{array}{l}\text { Latitude: } 8.5 \text {, } \\
\text { longitude: }-70\end{array}$ \\
\hline S8 & $\begin{array}{l}\text { Colombian Llanos } \\
\text { on high plains }\end{array}$ & $\begin{array}{l}\text { Seasonal and } \\
\text { hyperseasonal savanna }\end{array}$ & High plains close to Meta river. & $\begin{array}{l}\text { Latitude: } 4 \text {, } \\
\text { longitude: }-72.5\end{array}$ \\
\hline S9 & Guayana rain forest & Tropical rain forest & $\begin{array}{l}\text { Different areas on the Bolivar and } \\
\text { Amazonas States in Venezuela. Higher } \\
\text { values of NDVI. }\end{array}$ & $\begin{array}{l}\text { Latitude: } 5-7 \text {, } \\
\text { longitude: }-64 \text { to } \\
-67\end{array}$ \\
\hline S 10 & Control & Water & Areas with water (lakes, sea, rivers). & \\
\hline
\end{tabular}

The images were processed and displayed using ILWIS 2.2 (ILWIS, 1997). The data was processed to obtain the average, maximum and minimum NDVI values, standard deviation and confidence interval for each sampled area, and then the average values for each sampled area were displayed in a graph to have a preliminary green vegetation curve during the time. From this graph the lower values of NDVI, which are going down from the normal curve, were excluded, and the images, which have values greater than 0 , in places like lakes, rivers and sea, were excluded as well. The graphs resulting from this preliminary analysis are displayed again in order to obtain the final model curve for each area.

\subsection{Statistical analysis of the phenological patterns}

Two different approaches were used to select NOAA-NDVI images to run the classification. A vi- sual check of the NOAA-NDVI images resulted in the selection of 17 images following these criteria: (a) images containing the largest number of ecosystems, (b) the distribution of the selected images cover the maximum time amplitude, including the two seasons, (c) maximum variability and amplitude in NDVI values for each selected image.

Using a quality index based on the previous criteria, six images were selected for statistical analysis. These six images were analyzed using an ANOVA and posteriori Tukey's statistical test to recognize differentiation among the ecosystem classes.

\subsection{NOAA-AVHRR NDVI image classification}

Prior to the classification of the selected images, a sub-map of the Llanos del Orinoco area was created for each selected image. The area of these images was obtained using the limits defined in pre- 
vious vegetation, hydrographical, geology and soil maps.

A supervised classification based on the selection of training pixels was used. A sample set with representative pixels for each ecosystem was created, and used with a map list with the six selected images. Supervised classification is the digital-information extraction technique in which the operator provides training-site information that the computer uses to assign pixels to categories (Sabins, 1987). We used an alternative variation of the traditional technique, comparing the NDVI values of NOAA-AVHRR NDVI images instead of values of the bands for particular image (Aronoff, 1993).

Minimum Mahalanobis distance as a mathematical procedure was used to complete the classification (Bronsveld and Shrestra, 1993; Duda, 1997; ILWIS, 1997). After the classification process, the map was filtered to eliminate the areas or isolated pixels that produce noise, in order to obtain a map with homogeneous areas.

The final maps were combined with a mask of forest, agriculture, and savannas on Delta Plains, which are ecosystems not considered in the analysis of image classification. These masked ecosystems are derived from the vegetation map of Venezuela from Huber and Alarcón (1988).

\subsection{Validation of the classified ecosystems map}

To validate the accuracy of the final ecosystems map, samples set of 76 ground data were collected to confirm ecosystem units. The size of the ground data control was larger than $1 \mathrm{~km}^{2}$. A group of 15 data points were collected on the Calabozo area in the central Llanos of Venezuela on May 2000. Another group of 22 sample points was collected in the Apure flooding savanna area on December 1998. The major group of 39 sample points was collected in the Puerto Ayacucho area, and the western and central Llanos area in July and August 2000. This data was collected independently from the information derived in the map. A group of 28 ground data collected, containing unique information about the studied savanna ecosystems, was selected for the analysis. The data was compared to data derived from the ecosystem map of the Llanos del Orinoco and error matrices, kappa anal- ysis and descriptive technique analysis were used to measure the accuracy of the classification (Congalton et al., 1983; Congalton, 1991; Janssen and van del Wel, 1994).

\section{Results}

\subsection{Analyses of phenological pattern of savanna ecosystems}

Fig. 2 shows four phenological patterns from NDVI values, representing the three main savanna ecosystems in relation to the rainfall pattern (bars) obtanned from climatic stations in the area. NDVI values for S3 and S4 sampled areas were averaged because they presented similar patterns and $90 \%$ of overlaying in the seasonal patterns.

Hyperseasonal and seasonal savannas on tertiary plateau areas displayed the lowest NDVI values. During the 1992 rainy period, the values fluctuated between 0.40 and 0.45 . NDVI values decreased from the beginning towards the end of the dry period. However, a peak of increment was observed in March 1993, and then the values reached the lowest point. Between April and June 1993, the NDVI reached medium values; it increases from 0.20 to 0.45 as in the 1992 rainy period.

Semiseasonal savannas areas on alluvial plains showed the highest NDVI values. The pattern was bimodal during the rainy period, with the declination at middle-end of the rainy period, when flooding reached maximum values. During the dry period the NDVl values remained higher $(>0.55)$ until the middle of the dry period (January 1992). Afterwards, the values decreased to medium values (around 0.45 ) until the end of dry period. At the beginning of the new rainy period the NDVI again reached higher values.

The pattern for hyperseasonal and semiseasonal savannas on alluvial plains shows a stable curve of medium values (around 0.45) during the first rainy period. However, a clearly bimodal pattern was observed in the second rainy period with a large declination of NDVI vaiues during July and August 1993. During the dry period, the NDVI values remained medium until the beginning of January 1992, when they started to decrease, reaching the minimum lowest 

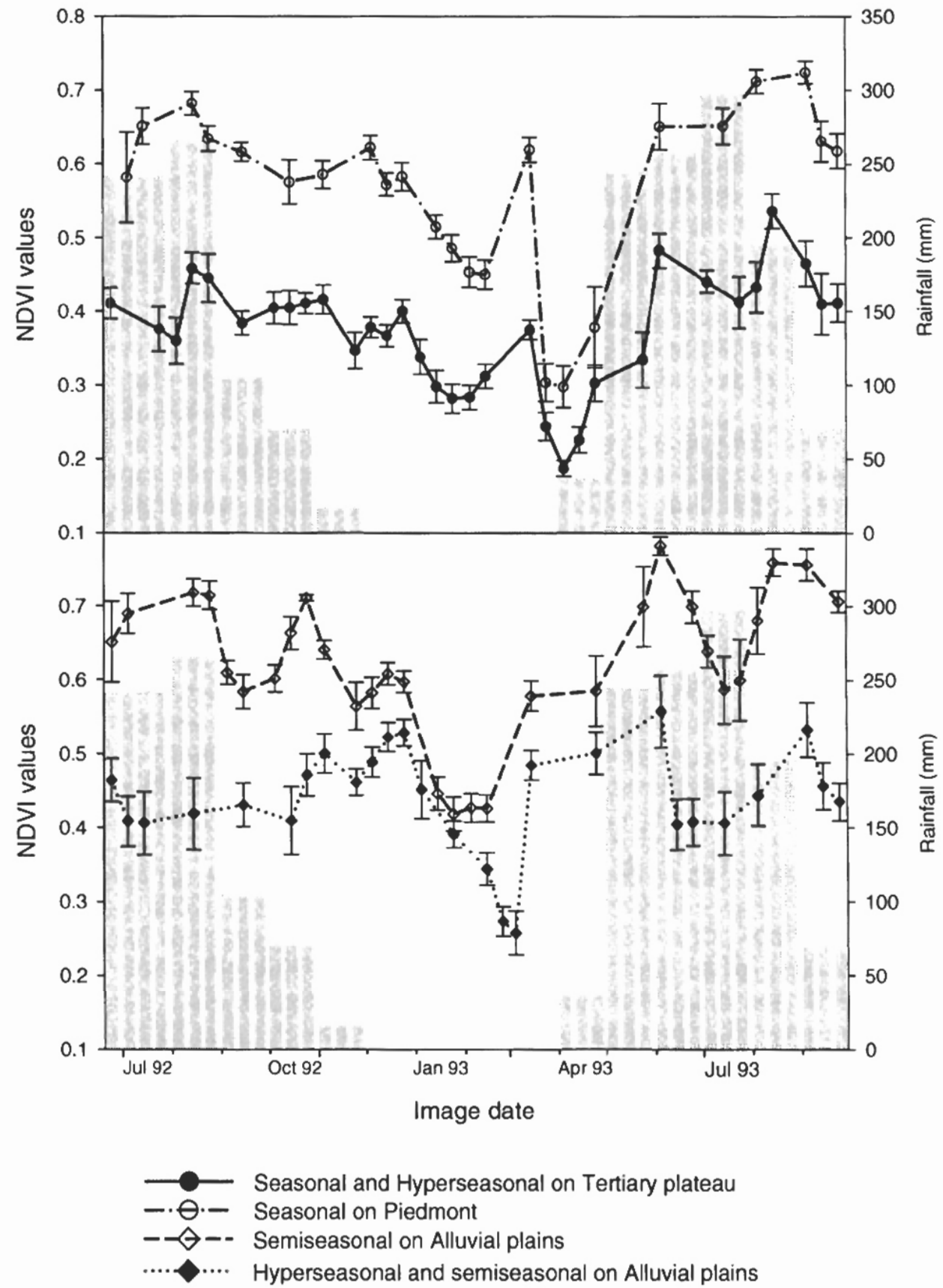

Fig. 2. Average NDVI values and standard errors for four different savanna ecosystems in the Llanos del Orinoco, Venezuela, between June 1992 and September 1993. Bars indicate the rainfall pattern recorded in San Fernando de Apure, Venezuela. 
value at the end of the dry period. At the beginning of the next rainy period, the values increased rapidly (March 1993).

A unimodal phenological pattern during the rainy periods for seasonal savannas on the piedmont was observed. Maximum NDVI values were obtained when the maximum rainfall values were reached a month later. The values remained medium-higher (around 0.50) 1 month after the rainfall stop. After that, the values started to decrease. At the end of the dry period the curve reached a peak and immediately the NDVI values fell to the minimum values. At the beginning of the new rainy period the NDVI values increased faster.

\subsection{Statistical analysis of the phenological patterns}

Based on the visual analysis of the phenological patterns, 18 NOAA-NDVI images were selected for the statistical analysis (Table 3 ). In this table, three criteria

Table 3

NOAA-NDVI images of the savanna ecosystems in the Llanos del Orinoco selected after a visual analysis

\begin{tabular}{|c|c|c|c|c|c|}
\hline No. & Image date & $\begin{array}{l}\text { Seasonal } \\
\text { period }\end{array}$ & A & B & $\mathrm{C}$ \\
\hline 9214 & 15 August 1992 & Rainy & 3 & 5 & Medium (15) \\
\hline 9215 & 25 August 1992 & Rainy & 3 & 4 & Low (12) \\
\hline 9217 & 15 September 1992 & Rainy & 4 & 5 & High $(20)^{\mathrm{a}}$ \\
\hline 9220 & 15 October 1992 & Rainy & 4 & 4 & Medium (16) \\
\hline 9221 & 25 October 1992 & Rainy & 4 & 3 & Low (12) \\
\hline 9222 & 5 November 1992 & $\begin{array}{l}\text { Transition: } \\
\text { rainy-dry }\end{array}$ & 5 & 5 & Highest $(25)^{\mathrm{a}}$ \\
\hline 9225 & 5 December 1992 & Dry & 4 & 5 & High $(20)^{a}$ \\
\hline 9227 & 25 December 1992 & Dry & 5 & 5 & Highest (25) \\
\hline 9303 & 25 January 1993 & Dry & 5 & 5 & Highest $(25)^{\mathrm{a}}$ \\
\hline 9305 & 15 February 1993 & Dry & 4 & 5 & High (20) \\
\hline 9308 & 15 March 1993 & Dry & 5 & 4 & High (20) \\
\hline 9310 & 5 April 1993 & Dry & 5 & 3 & Medium (15) \\
\hline 9312 & 25 April 1993 & $\begin{array}{l}\text { Transition: } \\
\text { dry-rainy }\end{array}$ & 4 & 5 & High $(20)^{\mathbf{a}}$ \\
\hline 9316 & 5 June 1993 & Rainy & 4 & 5 & High $(20)^{a}$ \\
\hline 9320 & 15 July 1993 & Rainy & 4 & 3 & Low (12) \\
\hline 9322 & 5 August 1993 & Rainy & 3 & 5 & Medium (15) \\
\hline 9325 & 5 September 1993 & Rainy & 4 & 5 & High (20) \\
\hline
\end{tabular}

Column A represents the number of lines differentiated from visual analysis in Fig. 3 for each image date, column B is the number of NOAA-NDVI images considered in those dates (point of image date), and column $\mathrm{C}$ is the quality index derived from the combination of columns $\mathrm{A}$ and $\mathrm{B}$.

a The selected images for statistical analysis. were taken into account to qualify the NOAA-NDVI images. Based on these criteria, it was found that the image dates of 5 December 1992, 25 January 1993 (beginning of the dry season), 5 November 1992, 25 April 1993 (transition periods), 15 September 1992 and 5 June 1993 (rainy period), had the best quality to separate the savanna ecosystems. However, this visual selection did not permit an evaluation of the confidence interval.

Fig. 3 shows the box plots of NDVI values of the six best images according to the previous analysis, and also considering the distribution of images during the study period. The ecosystems analyzed were grouped in five classes: seasonal savanna on tertiary plateau (3), seasonal and hyperseasonal savanna on tertiary plateau (4), semiseasonal savanna on alluvial plains (5), semiseasonal and hyperseasonal savanna on alluvial plains (6), and seasonal savanna on piedmont (SP) (7). For all dates the NDVI values for the seasonal (3) and hyperseasonal (4) savannas on tertiary plateau were similar. This observation was clear because the two phenological patterns follow the same way according to Fig. 3. For each date plot three and/or two kinds of value groups can be differentiated, and the dates 5 December 1992 and 5 November 1992 presented the best differentiation in four groups.

Table 4(a) and (b) shows the results for the ANOVA and Tukey's test of ecosystem savanna classes associated with Fig. 3. As was observed before, the seasonal (S3) and hyperseasonal (S4) savanna ecosystems on tertiary plateau never show significance differences. The best image date to make a differentiation amongst the classes was dated 5 November 1992. On the other hand, a combination of different dates distinguishes all the other ecosystem classes. The semiseasonal savanna ecosystem (S5) always has the highest separation index from seasonal and hyperseasonal savannas (S3 and S4). Furthermore, this ecosystem class was significantly separated from the hyperseasonal savanna (S6) in three of the images and with seasonal savannas on the piedmont (S7) in the other three image dates. Results of Table 4(b) confirms the statistical separation into different groups, indicating that the image date from the 5 th of November presents the major differentiation between classes. Also Table 4(b) shows that images from 25th April and 5th June permit a significant separation amongst four classes. 


\subsection{Ecosystems map of the Llanos del Orinoco, Venezuela}

Fig. 4 shows the ecosystems map for the Llanos del Orinoco, which is the result of supervised classification of NOAA-NDVI images.

The agriculture unit defines the annual agriculture and intensive agricultural areas. The distribution of
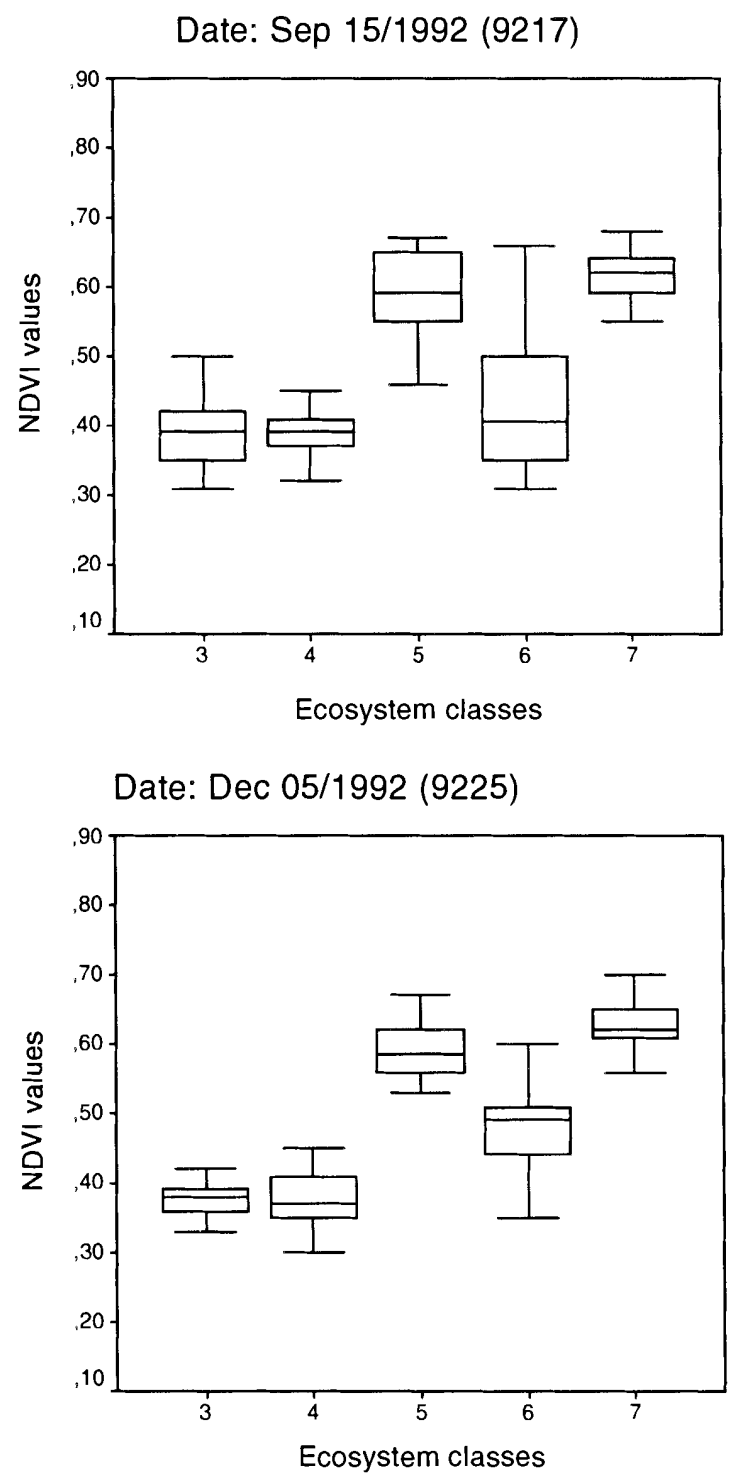

this unit replaces the seasonal savanna on the piedmont and alluvial plains.

The forest unit corresponds to the vegetation type associated to the river or watercourse, planted forest for pulp paper industry, and semiseasonal forest.

The hyperseasonal savanna unit is mainly located between the Apure and Arauca rivers, and at the north side of the high plains.

Date: Nov 15/1992 (9222)

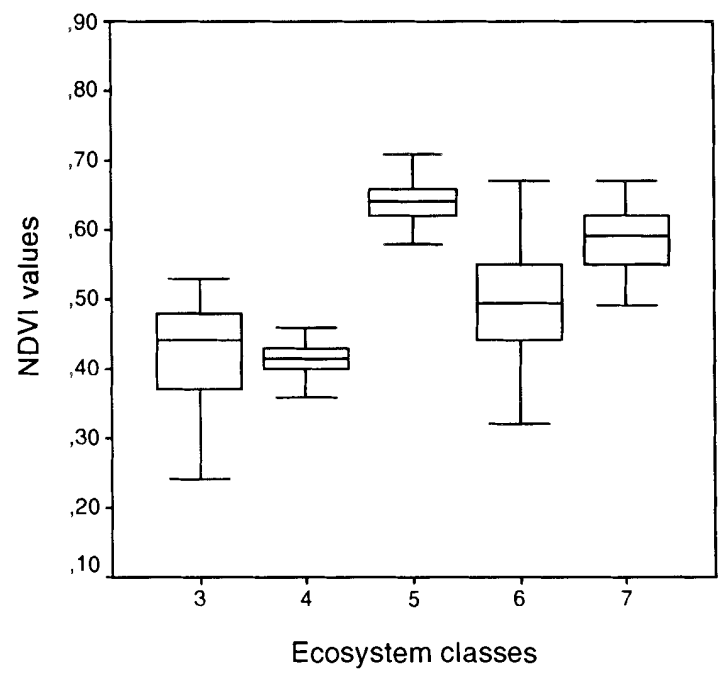

Date: Jan 25/1993 (9303)



Fig. 3. Boxplot of NOAA-NDVI values for the six main differentiate dates for the savanna ecosystems classes: 3 , seasonal savanna on tertiary plateau; 4 , seasonal and hyperseasonal savanna on tertiary plateau; 5 , semiseasonal savanna on alluvial plains; 6 , semiseasonal and hyperseasonal savanna on alluvial plains; 7 , seasonal savanna on piedmont. 
Date: Apr 25/1993 (9312)

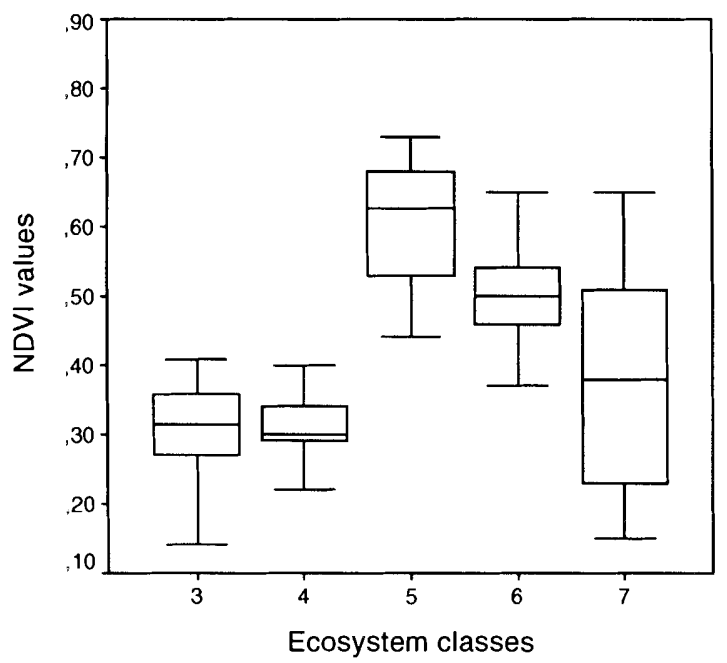

The savanna on Delta Plains unit is an ecosystem located on the overflow plains of the Orinoco Delta Area. The characteristics of this ecosystem are similar to the semiseasonal savanna, but the location is restrained to the Orinoco Delta Plains.

The seasonal and hyperseasonal savanna on tertiary plateau unit is the larger ecological unit in the Llanos del Orinoco. It is mainly located in or associated with the high plains in the central and eastern zone of the area. The seasonal savanna vegetation, with a strata of herbs (mainly grasses) with scatter tress, and the hyperseasonal savanna vegetation, with a main herbs strata, are present

The seasonal savanna on piedmont unit corresponds

Table 4

(a) Statistical significance of the results from the ANOVA of ecosystem classes for each image date selected, and (b) homogeneous groups derived from Tukey's test at significant level of 0.05

Date

(a)

$$
\text { S3 }
$$$$
\text { S3-S4 }
$$

15 September 1992 n.s.

5 November 1992 n.s.

5 December 1992

25 January 1993

25 April 1993

5 June 1993 n.s.

n.s.

n.s.

n.s.

)

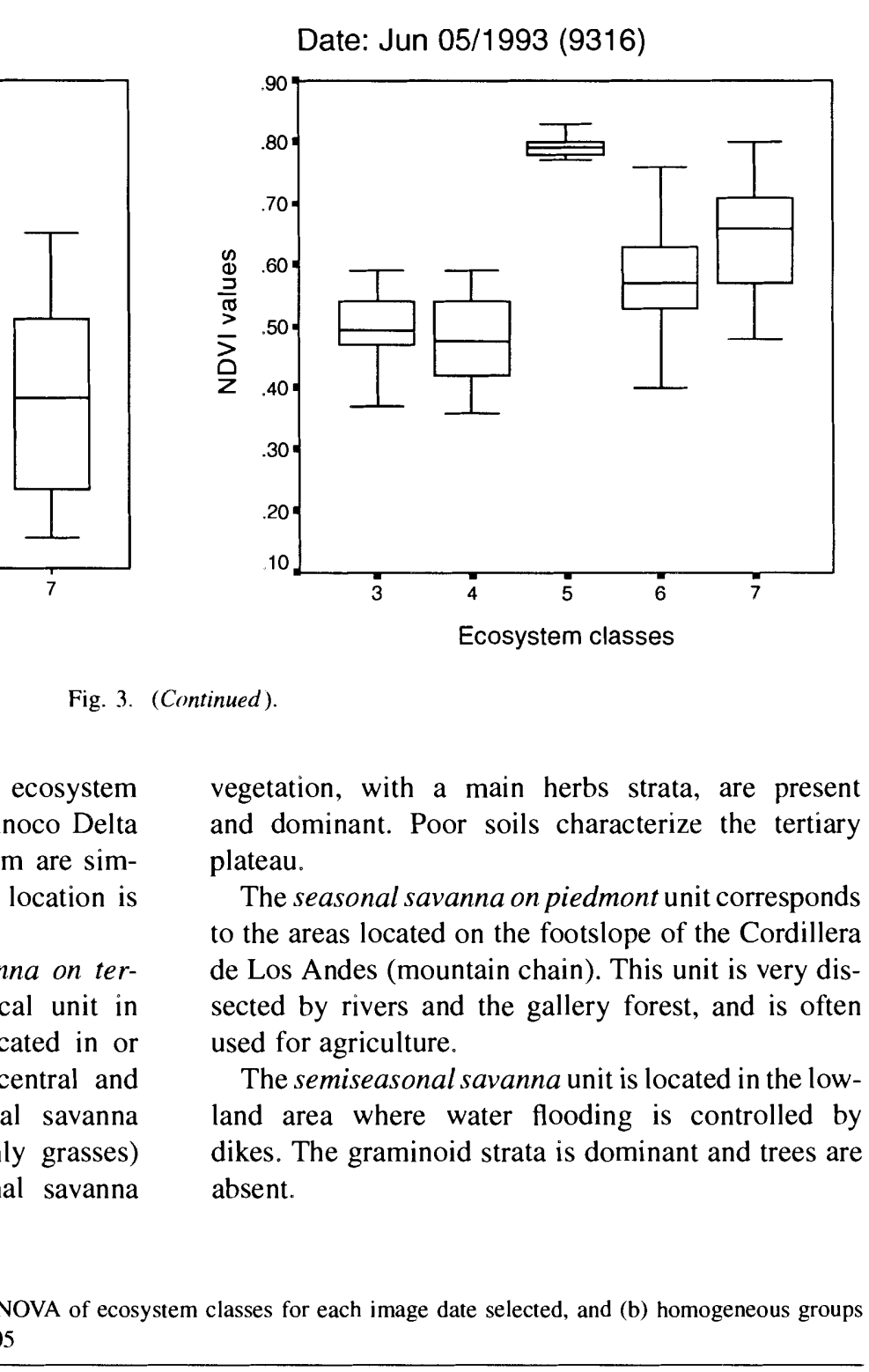

Date: Jun 05/1993 (9316)



Fig. 3. (Continued). and dominant. Poor soils characterize the tertiary plateau. to the areas located on the footslope of the Cordillera de Los Andes (mountain chain). This unit is very dissected by rivers and the gallery forest, and is often used for agriculture.

The semiseasonal savanna unit is located in the lowland area where water flooding is controlled by dikes. The graminoid strata is dominant and trees are absent.

5

(b)

$N$ equals 30 for the five ecosystem classes. Level of significance: n.s.: not significant, $* P<0.05, * * P<0.01$, and $* * * P<0.00 \mathrm{I}$. S3: plains, S6: semiseasonal and hyperseasonal savanna on alluvial plains, and S7: seasonal savanna on piedmont. 


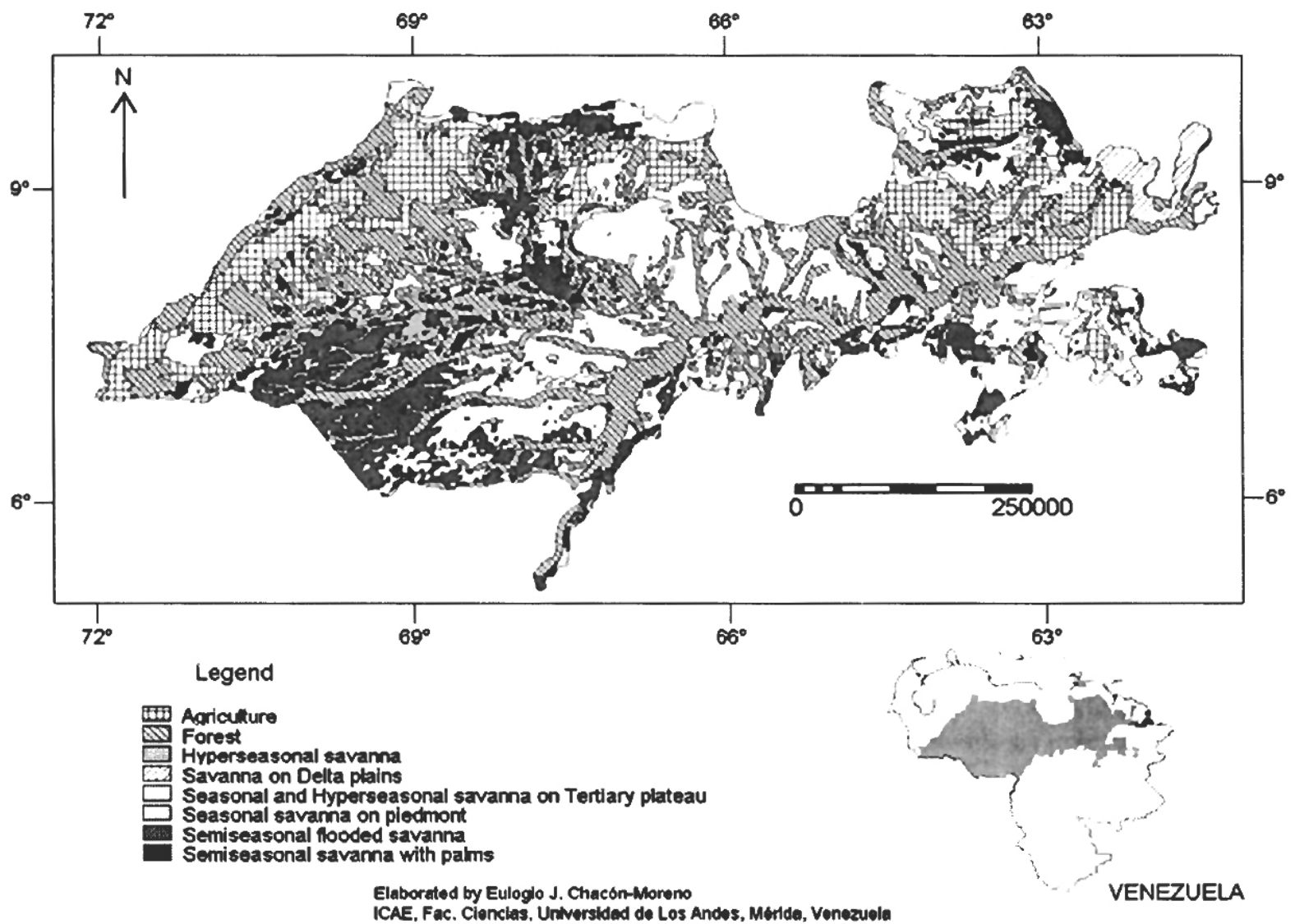

Fig. 4. Ecosystems map of the Llanos del Orinoco. Venezuela. Derived from supervised classification of NOAA satellite images based on Mahalanobis distance.

The semiseasonal savanna with palms unit is a variation of the semiseasonal savanna with a larger density of palms.

\subsection{Field validation of the ecosystems map}

Table 5 shows an error matrix comparing the reference data collected in the field and the data derived from the ecosystem map of the Llanos del Orinoco. The user's accuracy for the hyperseasonal $(\mathrm{H})$, seasonal and hyperseasonal on tertiary plateau (SHM), and seasonal savanna on piedmont was higher than $75 \%$, and only the semiseasonal savanna ecosystem (Sm) had user's accuracy below 50\%. All producer's accuracy values were above $60 \%$, which means that the probability of a reference pixel being correctly classified is higher. The overall accuracy was al-
Table 5

Error matrix for the ecosystems map of Llanos del Orinoco. Venezuela based on supervised classification of NOAA-NDVI images including only the classified savanna classes

\begin{tabular}{lcrllc}
\hline Classified image data & \multicolumn{6}{l}{ Reference data } \\
\cline { 2 - 6 } & H & SHM & SP & Sm & Row total \\
\hline H & 3 & 0 & 0 & 1 & 4 \\
SHM & 0 & 11 & 0 & 0 & 11 \\
SP & 0 & 0 & 4 & 0 & 4 \\
Sin & 2 & 1 & 2 & 4 & 9 \\
Column total & 5 & 12 & 6 & 5 & 28 \\
\hline
\end{tabular}

$\mathrm{H}$ : hyperseasonal savanna. SHM: seasonal and hyperseasonal savanna on tertiary plateau. SP: seasonal savanna on piedmont, Sm: semiseasonal savanna. kappa analysis was significant. Producer's accuracy: $\mathrm{H}=3 / 5=60 \%, \mathrm{SHM}=11 / 12=92 \%, \mathrm{SP}=4 / 6=$ $67 \%, \mathrm{Sm}=4 / 5=80 \%$. User's accuracy, $\mathrm{H}=3 / 4=75 \%$. $\mathrm{SHM}=11 / 11=100 \%, \mathrm{SP}=4 / 4=100 \%, \mathrm{Sm}=4 / 9=44 \%$. Overall accuracy, $22 / 28=79 \%$. Kappa value $=0.70$. 
most $80 \%$. Besides, the value of kappa analysis was significant and high.

\section{Discussion and conclusions}

Based on analysis of multitemporal NOAA-AVHRR NDVI imagery, phenology of vegetation was determined to better understand the ecology of the main ecosystems of the Llanos del Orinoco. It was analyzed in order to correlate vegetation dynamics with environmental parameters and features. A previous knowledge of ecosystem functioning and the features of the study area was necessary to understand and explain the phenological patterns derived from the remote sensing data.

The phenological patterns presented in Fig. 2 showed a good relation with those expected from Fig. 1. Most of the changes and line patterns can be explained based on the changes in phenology associated with climatic changes (seasonality). Seasonal and hyperseasonal savanna ecosystems on tertiary plateau showed lower values during the dry period associated with the senescence of the plant. Another likely explanation is that fire occurs mainly in this kind of savanna, so that the sensor observes ashes and soil. The lowest values were found on the tertiary plateau on very poor soils, and presumably because reflection from the soil is high and produces low values in the infrared band and high values in the red band, then the NDVI values are low.

The phenological patterns of semiseasonal savannas on alluvial plains can be explained by overflows in the area. After the rainfall decreases, the soil maintains field capacity, the vegetation remains green and the values are high. But when field capacity decreases, the vegetation dries up and the NDVI is low. When rainfall begins, the vegetation starts to grow and NDVI becomes high again. The values of NDVI represented a high productivity of grass vegetation, mainly due the C4 metabolism and water availability during whole year.

Hyperseasonal and semiseasonal savanna vegetation remained green (high NDVI values) because there was still water in the soil, but when soil water availability decreased in the dry period (stress by water deficit), the green vegetation started to disappear, then the values of NDVI decreased, too. During the middle of the second rainy period values decreased, probably because the water level was high and mask the infrared radiation of the green vegetation, then the sensor observe a mixture of water and green vegetation.

The seasonal savanna on the piedmont presented decreasing values of NDVI during the dry period is explained by a decrease in water availability. But the isolated peak at the beginning of the rainy period could be explained by the permanence of crops, and/or a short period of growth at the beginning of the rainy season followed by fire. The increasing values during the rainy period are related to the growth period of savanna vegetation and annual crops in the area.

The patterns of phenological variation for each of the ecosystems show a strong relationship with the environmental features described by Sarmiento (1983, 1990), Sarmiento et al. (1971a,b), Silva et al. (1971), and Chacón-Moreno (1999), where the annual distribution of rainfall determines conditions of water availability. The patterns also depend on other characteristics such as the geomorphology of the areas where this ecosystem exists.

The major fluctuations and growth of vegetation are associated with the rainfall period, while decreasing NDVI values are associated with the dry period. However, in some ecosystems such as the hyperseasonal savanna, the reduced values during the rainy period are due to flooding. On the other hand, the presence of high values during the dry period for ecosystems like the semiseasonal savanna denotes water availability in the soil to maintain the green vegetation during this non-favorable hydrological period.

The interpretation of these phenological patterns is useful to identify and select a pool of NOAA-AVHRR NDVI images in contrasting periods to produce a map based on the image-supervised classification. The map units correspond to the ecosystems analyzed.

The classification accuracy of the Ecosystems map was good with an overall accuracy of $79 \%$, therefore the classification of the savanna classes derived from the analysis of the phenological patterns of savanna ecosystems was satisfactory. On the other hand, the extension of the agricultural units derived from previous maps indicates that some important changes in land use have been occurring.

Using analysis of the multitemporal NOAA-AVHRR NDVI imagery, it was possible to reveal the phenology of the most important ecosystems in the savanna 
area of Venezuela. This methodology allows a link between the ecological processes with spatial components of the remotely sensed data.

\section{Acknowledgements}

This work was supported by the Consejo de Desarrollo Científico, Humanístico y Tecnológico (CDCHT), Universidad de Los Andes, Mérida, Venezuela (project C-706-95-01). I would also like to thank the International Institute for Aerospace Survey and Earth Sciences (ITC), The Netherlands for their collaboration in the research. This paper corresponds to Chapter 3 of the E.J. Chacón-Moreno Ph.D. Thesis. I thank the International Geosphere Biosphere Program for the use of the global land $1 \mathrm{~km}$ NOAA image data set. I also thank María Bastidas and Guillermo Calderón for their suggestions and friendship during E.J. Chacón-Moreno stay in Enschede. I appreciate the valuable collaboration of Maryelis Pabón, Daniela and Rebeca Chacón for the assistance during the fieldwork validation. Finally, I would like to thank Dr. R.H.G. Jongman and Dr. Prof. I.S. Zonneveld for helpful comments, and Dr. F. Rada for the review of the manuscript.

\section{References}

Acevedo, M.. Silva, J., 1985. Proyecto Orinoco-Apure. Información Ambiental y Ecológica sobre los Llanos del río Orinoco MARNR, Dirección General Sectorial de Planificación y Ordenación del Ambiente

Aronoff, S., 1993. Geographic Information System: A Management Perspective. WDL Plublications, Canada.

Azzali, S., Menenti, M., 1999. Mapping isogrowth zones on continental scale using temporal Fourier analysis of AVHRR-NDVI data. Int. J. Appl. Earth Observ. Geoinform. I (1), 9-20.

Batista, G.T., Shimabukuro, Y.E., Lawrence, W.T., 1997. The long-term monitoring of vegetation cover in the Amazonian region of northern Brazil using NOAA-AVHRR data. Int. J. Remote Sens. 18 (15), 3195-3210.

Bronsveld, K., Shrestra, D.. 1993. Tutorial for Image Processing Using ILWIS. Remote Sensing and GIS Module, Version I.4. ITC, Enschede, The Netherlands.

Chacón-Moreno, E., 1991. Vegetación y Flora de la Sabanas venezolanas. Plan de Ordenación y Manejo del Parque Nacional Santos Luzardo. Tomo I. En BIOMA-MARNR, Caracas, Venezuela, Capítulo 3.2.1, pp. 38-82.

Chacón-Moreno, E., 1999. Patrones Fenológicos de vegetación de los Llanos del Orinoco, Venezuela, a través de análisis de series de tiempo de imágenes NOAA. In: En Ponte, R. (Ed.). Memorias del VII Conferencia lberoamericana sobre Sistemas de Información Geográfica, Mérida. Recurso Multimedia.

Congalton. R.G.. 1991. A review of assessing the accuracy of classifications of remotely sensed data. Remote Sens. Environ. 37, $35-46$.

Congalton, R.G., Oderwald, R.G., Mead, R.A., 1983. Assessing landsat classification accuracy using discrete multivariate analysis statistical techniques. Photogramm. Eng. Remote Sens. 49 (12), 1671-1678.

Duchemin, B., Goubier, J., Courrier, G., 1999. Monitoring phenological key stages and cycle duration of temperate deciduous forest ecosystems with NOAA/AVHRR data. Remote Sens. Environ. 67, 68-82.

Duda, R.. 1997. Pattern Recognition for $\mathrm{HCl}$. Human Computer Interface Design. A New Multi-University Course Sponsored by the National Science Foundation, http://www-engr.sjsu.edu/ $\sim$ knapp/hcirodpr/pr_Maha/M_metic.htm.

Eidenshink, J.C., Faundeen, J.L., 1998. The I km AVHRR Global Land Data Set: First Stages in Implementation. US Geological Survey, EROS Data Center, Sioux Falls, South Dakota 57198 , USA.

Groten, S.M.E., 1993a. From monttoring to management-experiences from NOAA-NDVI application research in semi-arid Africa. In: Proceedings of the International Symposium on Operationalization of Remote Sensing, vol. 4. Enschede. pp. 15-26.

Groten. S.M.E., 199.3b. Earth observation for ecologic hazard mitigation and prevention. ITC J. 1993-4.

Hill, M.J., Vickery, P.J., Furnival, E.P., Graham, E.D., 1999. Pasture land cover in eastem Australia from NOAA-AVHRR and classified landsat TM. Remote Sens. Environ. 67, 32-50.

Hobbs, R.J., 1989 Remote sensing of spatial and temporal dynamics of vegetation. In: Hobbs, R.J., Mooney, H.A. (Eds.), Remote Sensing of Biosphere Functioning. Ecological Studies 79. Springer-Verlag. Berlin.

Huber, O., Alarcón, C., 1988. Mapa de vegetación de Venezuela. Ficiala 1:2.000.000. Editorial Arte. S.A., Caracas, Venezuela.

Hueck, K.. Seibert. P.. 1988. Mapa de la vegetación de América del Sur. Deutsche Gesellschaft fur Technische Zusammemarbeit (GTZ) GmbH, Germany.

ILWIS, 1997. Reference Guide. ILWIS Department, ITC, Enschede.

Janssen, L.L.F., van del Wel, F.J.M., 1994. Accuracy assessment of satellite derived land-cover data: a review. Photogramm. Eng. Remote Sens. 60 (4), 419-426.

Kressler, F.P., Steinnocher, K.T., 1999. Detecting land cover changes from NOAA-AVHRR data by using spectral mixture analysis. Int. J. Appl. Earth Observ. Geoinform. I (1), 2l-26.

Loveland, T.R., Belward. A.S., 1997. The IGBP-DIS global I km cover data set, DISCover: first results. Int. J. Remote Sens. 18 (15), 3289-3295.

Loveland, T.R., Zhu, Z., Ohlen, D.O., Brown, J.F., Reed, B.C., Yang, L., 1999. Quantitative analysis of the global land-cover characterization process. Photogramm. Eng. Remote Sens. 65 (9), 1021-1032.

MARNR, 1983. Venezuela en Mapas. Departamento de Cartografía Temática, División de Mapas, Caracas. Venezuela. 
Menenti. M., Azzali, W., Verhoef, W., Van Swol, R., 1991. Mapping Agro-ecological Zones and Time Lag in Vegetation Growth by Means of Fourier Analysis of Time Series of NDVI Images. Rep. 32, DLO-Winand Staring Centre, Wageningen, The Netherlands, $46 \mathrm{pp}$.

Monasterio, M., Sarmiento, G., 1976. Phenological strategies of plant species in the tropical savanna and the semi-deciduous forest of the Venezuelan Llanos. J. Biogeogr. 3, 325-356.

Monasterio, M., Sarmiento, G., y Silva, J., 1971. Reconocimiento ecológico de los Llanos Occidentales. III. El sur del Estado Barinas. Acta Cient. Venezolana 22 (5), 153-169.

Ramia, M., 1959. Las Sabanas de Apure. Ministerio de Agricultura y Cria. Dirección de Recursos Naturales Renovables. Caracas, Venezuela.

Reed, B.C., Brown, J.F., van der Zee, D., Loveland, T.R., Merchant, J.W., Ohlen, D.O., 1994. Measuring phenological variability from satellite imagery. J. Veg. Sci. 5, 703-714.

Sabins, F.F., 1987. Remote Sensing. Principles and Interpretation. Freeman, New York

Sarmiento, G., 1983. The savannas of tropical America. In: Bourliére, F. (Ed.), Tropical Savannas. Elsevier, Amsterdam, pp. 245-288.

Sarmiento, G., 1984. The Neotropical Savannas. Harvard University Press, Cambridge.
Sarmiento, G., (Ed.) 1990. Las sabanas americanas. Aspecto de su biogeografía, ecología y utilización. Fondo Editorial Acta Científica Venezolana, Caracas, Venezuela.

Sarmiento, G., Monasterio, M., 1971. Ecología de las sabanas de América Tropical. I. Análisis macroecológico de los Llanos de Calabozo. Venezuela Rev. Geogr. 21, 5-38.

Sarmiento, G., Monasterio, M., 1975. A critical consideration of the environmental conditions associated with the ocurrence of savanna ecosystems in tropical America. In: Golley, F., Medina, E. (Eds.), Tropical Ecological Systems. Springer-Verlag, New York, pp. 223-250.

Sarmiento, G., Monasterio, M., Silva, J., 197la. Reconocimiento ecológico de los Llanos Occidentales. I. Las unidades ecológicas regionales. Acta Cient. Venezolana 22 (2), 52-59.

Sarmiento, G., Monasterio, M., Silva, J., 197lb. Reconocimiento ecológico de los Llanos Occidentales. IV. El oeste del Estado Apure. Acta Cient Venezolana 22, 170-180.

Silva, J., Monasterio, M., y Sarmiento, G., 1971. Reconocimiento ecológico de los Llanos Occidentales. II. El norte del Estado Barinas. Acta Cient. Venezolana 22 (2), 60-70.

Stone, T.A., Schlesinger, P., Houghton, R.A., Woodwell, G.M., 1994. A map of the vegetation of South America based on satellite imagery. Photogramm. Eng. Remote Sens. 60 (5), 541551. 